Cinémas

Revue d'études cinématographiques

Journal of Film Studies

\title{
Cinéma québécois et réception critique aux États-Unis
}

\section{Louise Carrière}

Volume 7, numéro 3, printemps 1997

Cinéma québécois et États-Unis

URI : https://id.erudit.org/iderudit/1000949ar

DOI : https://doi.org/10.7202/1000949ar

Aller au sommaire du numéro

Éditeur(s)

Cinémas

ISSN

1181-6945 (imprimé)

1705-6500 (numérique)

Découvrir la revue

Citer cet article

Carrière, L. (1997). Cinéma québécois et réception critique aux États-Unis. Cinémas, 7(3), 61-80. https://doi.org/10.7202/1000949ar

\section{Résumé de l'article}

La critique états-unienne de la grande presse aborde chaque film québécois indépendamment de la problématique propre à son auteur ou à la cinematographie en général. Elle accueille favorablement un type de film d'action qui se démarque du cinéma états-unien, mais tolère difficilement un cinéma intimiste et introverti. À son insu, ses critères d'appréciation et ses centres d'intérêt révèlent la faible distance critique d'avec le cinéma hollywoodien et les valeurs admises d’une société de consommation qui la caractérisent. 


\title{
Cinéma québécois et réception critique aux États-Unis
}

\section{Louise Carrière}

\begin{abstract}
RÉSUMÉ
La critique états-unienne de la grande presse aborde chaque film québécois indépendamment de la problématique propre à son auteur ou à la cinématographie en général. Elle accueille favorablement un type de film d'action qui se démarque du cinéma états-unien, mais tolère difficilement un cinéma intimiste et introverti. À son insu, ses critères d'appréciation et ses centres d'intérêt révèlent la faible distance critique d'avec le cinéma hollywoodien et les valeurs admises d'une société de consommation qui la caractérisent.
\end{abstract}

\section{ABSTRACT}

Film criticism in the major American newspapers looks at Quebecois films without regard either for their authors' problematics or for cinematography in general. It views with favour a certain type of action film which differs from American cinema, but has difficulty tolerating an intimate or introverted film. Unconsciously, its evaluation criteria and centres of interest reveal how close this criticism is to the Hollywood film-making industry and the values it projects in a consumer society.

Avant 1978, la critique états-unienne connaît le cinéma québécois grâce à quelques succès et à quelques auteurs vedettes. Les films d'auteurs $A$ tout prendre (Claude Jutra, 1963), Kamouraska (Claude Jutra, 1973), Les Ordres (Michel Brault, 1974) et Mon oncle Antoine (Claude Jutra, 1971) demeurent les films 
francophones les plus appréciés; Nobody Waved Goodbye (Donald Owen, 1964), Lies My Father Told Me (Jan Kadar, 1974), Apprenticeship of Duddy Kravitz (Ted Kotcheff, 1974), City Of Fire (Alvin Rakoff, 1978), The Brood (David Cronenberg, 1979), Death Ship (Alvin Rakoff, 1980) et The Little Girl Who Lives Down The Lane (Nicholas Gessner, 1976), réalisés en anglais, comptent parmi leurs préférés '.

Pourtant, il n'y a pas nécessairement concordance entre accueil critique et succès au box office. Ainsi, les films québécois tournés directement en anglais qui connaissent du succès aux États-Unis, et qui sont pour la plupart distribués par les Majors - Speed Zone (Jim Drake, 1989), Porky's (Bob Clarke, 1981), Scanners (David Cronenberg, 1980) —, seront rarement encensés par la critique états-unienne. Au contraire, les films aux impacts commerciaux modestes, Montreal Main (Frank Vitale, 1973), Isabel (Paul Almond, 1968), One Man (Robin Spry, 1977) et High (Larry Kent, 1967) trouveront bonne grâce à ses yeux. Du côté des rentrées d'argent, peu de films québécois tournés en français ont fait sensation. Seuls deux films d'Arcand ont produit de bonnes recettes, soit $1902000 \$$ pour Le Déclin de l'empire américain et $1602612 \$$ pour Jésus de Montréal. En comparaison, Un zoo, la nuit n'a rapporté que 43978 \$ malgré des concessions au cinéma de spectacle. Dans un marché étatsunien à $95 \%$ autosufffisant, y a-t-il de la place pour les films québécois? La critique états-unienne, à l'image des Majors, joue-t-elle un rôle de bouclier face à la pénétration des films québécois chez elle?

Depuis l'époque des premiers films de fiction québécois des années soixante et soixante-dix, la critique états-unienne a-t-elle modifié ses préférences? Que nous dévoile-t-elle du Québec, de son cinéma et aussi d'elle-même? J'ai cherché à y répondre en m'appuyant sur un certain nombre de films et de textes critiques ${ }^{2}$.

Mais auparavant, il est bon de rappeler que le cinéma québécois lui-même a évolué rapidement à partir de 1978. Les longs métrages se sont multipliés, ainsi que les films réalisés pour la télévision. De trois à cinq longs métrages par année, la production cinématographique québécoise a grimpé de six à 10 longs métrages puis, en 1991, à une trentaine de longs métrages. Le 
phénomène d'hybridité des productions relié aux politiques canadiennes d'abris fiscaux s'accentue durant les années quatrevingt. Ainsi s'intensifie la tendance à la coproduction et à l'internationalisation, suscitant une interrogation sur la place laissée à la spécificité québécoise. Le cinéma québécois cherche, entre autres, à occuper un terrain laissé jadis vacant: le cinéma de genres, développé depuis des décennies par les grands cinémas nationaux. Ces nouvelles orientations questionnent de plus belle les composantes américanité-américanisation des films québécois. "Should Canadian dollars continue to be spent in a vain attempt to emulate Hollywood at its second-rate best?" se demandait déjà en 1980 Arthur Knight du Hollywood Reporter (p. 13). De plus, les changements opérés dans les modes de production et de financement mettent en lumière, avec plus de relief que jamais, le problème de l'identité:

Cette volonté du cinéma québécois d'intérioriser au sein de ses catégories originelles des catégories qui lui sont étrangères et qui apparaissent contradictoires par rapport aux premières, cette projection sous la forme du semblable et du dissemblable, intériorisant son altérité, est le signe qu'il est plus que jamais en quête de luimême, à la fois sujet d'énonciation et sujet d'énoncé ${ }^{3}$.

Les réalisations des dernières années se bousculent dans ce contexte de redéfinition politique et culturelle. Les critiques étatsuniens ont-ils perçu cette évolution? Quelle est leur perception des films québécois plus récents?

Pour y voir clair, j'ai retenu 11 films québécois réalisés entre 1978 et 1992 dont on retrouve les traces dans les journaux étatsuniens tels que répertoriés par le Centre de recherche cinéma/ réception de l'Université de Montréal (CRC/R). Dans ce choix, j'ai éliminé les films produits au Québec, mais dont les réalisateurs et titres sont associés à un cinéma d'une autre nation (comme Louis Malle, Claude Chabrol, Tony Richardson, respectivement réalisateurs des films Atlantic City, Violette Nozière et The Hotel New Hampshire, produits au Québec). Les films choisis ont fait l'objet d'un grand nombre de textes critiques à l'intérieur d'une quinzaine d'années et ont été retenus dans une première étape: Les Bons Débarras (Francis Mankiewicz, 1979), 
Maria Chapdelaine (Gilles Carle, 1983), Visiting Hours (JeanClaude Lord, 1981), The Bay Boy (Daniel Petrie, 1984), Un zoo, la nuit (Jean-Claude Lauzon, 1987), Pouvoir intime (Yves Simoneau, 1986), Joshua, Then And Now (Ted Kotchef, 1985), Les Plouffe (Gilles Carle, 1981), Comment faire l'amour avec un nègre sans se fatiguer (Jacques Wilbrod Benoît, 1989), The Kid Brother (Claude Gagnon, 1987), Léolo (Jean-Claude Lauzon, 1992), et les films de Denys Arcand Le Déclin de l'empire américain et Jésus de Montréal. À la lumière de relectures, les films souvent cités par la critique, mais dont les textes répertoriés comportaient peu d'éléments critiques ou analytiques ont été retirés: Joshua, Then and Now, The Kid Brother.

Les remarques des critiques états-uniens sont regroupées selon différents paramètres présents dans les textes: la présentation du cinéaste et de son œuvre, l'intérêt pour le sujet et le milieu social, la moralité des films québécois et la place qu'ils assignent à la religion, l'appréciation des acteurs, des procédés cinématographiques et de la narration.

\section{Présentation du cinéaste et de son œuvre}

De manière générale, les textes critiques répertoriés par le $\mathrm{CRC} / \mathrm{R}$ qui proviennent principalement d'une presse cinématographique corporative méconnaissent l'œuvre d'ensemble des auteurs. Les textes situent rarement le film dans la carrière cinématographique de son auteur ou au sein de la cinématographie québécoise. Plus encore, il arrive que l'auteur soit tout simplement remplacé par le producteur. Le réalisateur de Maria Chapdelaine, Gilles Carle, est éclipsé au profit de "[...] Harold Greenberg, executive producer of the highest-grossing picture in the history of the Canadian film industry (Porky's), [who] can now be claimed to making "The Great Canadian Film " (L.A. Weekly). De Francis Mankiewicz et de sa démarche, on dira simplement: "Mankiewicz has directed a film that moves inexorably forward with the single-mindedness of Greek tragedy " lywood Reporter). De Jacques Benoît et de Comment faire l'amour avec un nègre sans se fatiguer: "Benoît does not make an auspicious film debut" (The Hollywood Reporter) ou "A first feature by white director, Jacques W. Benoît" (The Village Voice). 
Un jeune auteur, Jean-Claude Lauzon, échappera à l'anonymat et à la parcimonie des habituelles présentations d'auteurs québécois. À propos du réalisateur d'Un zoo, la nuit, on écrira: "The first feature by the 34-year-old director of TV commercials, Jean-Claude Lauzon, this high-powered French Canadian production won the critics prize at the " 87 " Toronto Festival of Festivals" (The Village Voice). Ou encore:

\begin{abstract}
The heralded French-Canadian film Night Zoo marks the directorial debut of Jean-Claude Lauzon, a filmmaker with an authoritative command of the medium, a fresh perspective and a tendency to bite off more than he can convincingly chew. Having grown up in a tough Montreal neighborhood and spent some time in a reform school, Lauzon knows his milieu, the erosion of despair, the eat-or-be-eaten attitude of the battered characters (Films In Reviews).
\end{abstract}

Et, en introduction à Léolo, on fait simplement un bref rappel qu'il y a cinq ans, Lauzon réalisait $U n$ zoo, la nuit. Les cinéphiles états-uniens n'ont qu'à bien se tenir et à se souvenir!

Gilles Carle, sexagénaire, réalisateur depuis 1958, semble le seul dont on mentionne la continuité dramatique. Les Plouffe, réalisé en 1982, est précédé d'informations sur les antécédents de ce pionnier:

In contrast, the 1968 Red is imbued with Godardian throwaway aesthetics: jumpcuts and junk culture, shiny colors and fast cars. It's easy to see why Carle was Quebec's hottest cineaste a decade or so ago; there's more than enough fuel to burn in this tale of a handsome half-breed hoodlum (The Village Voice).

On y apprend avec surprise que l'œuvre de Carle s'apparente aux films de sexploitation québécois: «Mr. Carle best known in his country for the sexy films (Normande, Fantastica) starring his wife, Carole Laure, is a perfectly competent film maker but not an exciting one" (The New York Times).

Denys Arcand qui, avec Le Déclin de l'empire américain, couronne plus de 20 ans de réalisation cinématographique est simplement perçu comme un réalisateur chevronné de l'ONF 
(dont il n'est pas un employé) ou alors comme un écrivain adaptant à l'écran son propre roman, Dirty Conversations (Film Comment).

\section{Intérêt pour le sujet et le milieu social}

Faute d'être loquace et bien informée sur les auteurs, la critique états-unienne se prononce avec force sur la transposition des réalités québécoises, sur les milieux sociaux et les représentations de l'imaginaire. Un des attraits des films réside, selon elle, dans la représentation des paysages et des réalités rurales, pour laquelle louanges et descriptions élaborées vont de pair, en opposition à la description des milieux urbains. De Maria Chapdelaine, on en apprendra plus sur son cadre géographique que sur son réalisateur:

The film describes the harsh conditions and hardships of turn of the century rural life in Quebec's north. This was not an easy film to make. The prop master personnaly logged a 7,200 miles on his truck during the first few weeks of shooting. Location was 300 kilometers (200 miles) north of Montreal. The area, with an average annual snowfall of 110 inches, barely got 10 inches in the unusual winter of 1982-83 (L. A. Weekly).

La différence du contexte géographique fascine la critique. Ainsi, en ce qui a trait à Bay Boy: "Setting is a coastal mining community circa 1937" (Variety Film Reviews Index). Il est avant tout un film qui commence lentement pour nous donner "[...] a nice flavor for Glace Bay and its people" (The Hollywood Reporter).

The Bay Boy is a memory film, autobiographical in tone, that is covered by a scrim of nostalgia. The writer-director, Daniel Petrie, has opened a comparatively new territory for his camera, the town of Glace Bay, on Cape Breton Island in Nova Scotia. Here it serves as background, without freeways or urban cries in the night, for film action (The New York Times).

Les films québécois, encore imprégnés par le passé, même s'ils se situent dans les milieux urbains, bénéficient encore de la 


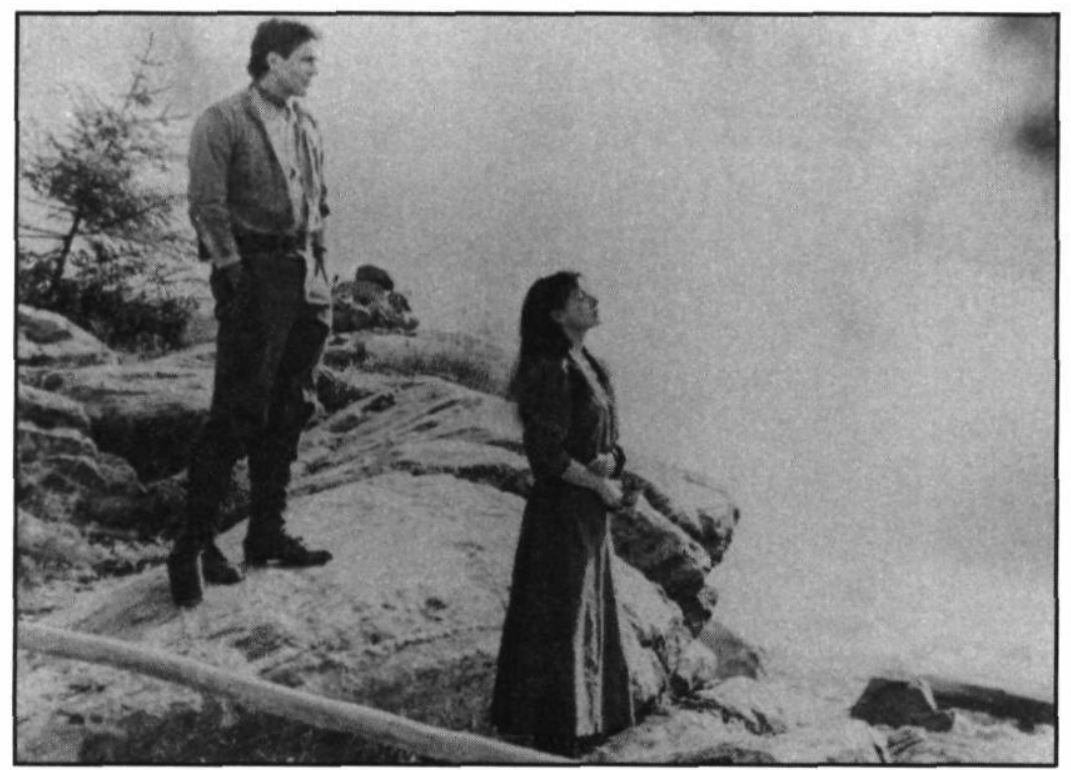

\section{Maria Chapdelaine de Gilles Carle (1983)}

Collection Cinémathèque québécoise

complicité des critiques. Ainsi pour Les Plouffe, les États-Uniens perçoivent avant tout ceci :

It is much to the credit of screenwriters Lemelin and Carle that Les Plouffe has steered a wide path around political propaganda. It is simply the recreation of a period, with perspectives and attitudes of that time intact (Variety Film Reviews Index).

1938-1945... Those years saw the early rumblings of the French-Canadian separatist movement in Quebec as well as the gathering and breaking storm or World War II (The Hollywood Reporter).

Par contre, l'originalité et l'exotisme des films canadiens s'effacent complètement lorsqu'il s'agit de représentations du Québec contemporain et des milieux urbains. Ainsi on déplore que, pour Pouvoir intime, Simoneau ait échafaudé une série de relations qui aboutissent nulle part: la relation mélodramatique d'un père et de son fils, une ancienne romance, une liaison homosexuelle entre un gardien psychosé et un beau serveur: 
" [...] that's insubstantial, one wonders why $P I$ was selected this year's Gay Film Festival» (The Village Voice). "Simoneau takes viewers for a plunge inside Montreal's sordid underbelly on a botched-up heist of an armored, cash-laden van " (Variety Film Reviews Index). C'est sans doute le film de Jacques Benoît, Comment faire l'amour avec un nègre sans se fatiguer, et celui de JeanClaude Lord, Visiting Hours, qui s'attirent le plus les foudres de la critique. Jouant, dit-on, sur tous les préjugés que les Blancs ont sur les Noirs, le film de Benoît inverse la perspective habituelle en fixant l'objectif cette fois sur les Noirs, mais sans jamais vouloir vaincre les stéréotypes:

Neither film attempts to break down stereotypes: both films champion non-whites exploiting whites. The female nudity and several somewhat graphic sex scenes in "How..." will make or break the film (Variety Film Reviews Index).

This is not a viable movie on any level and is a total failure as social commentary. Benoît does not make an auspicious film debut. His staging is painfully dull and he fails to capture any urban rythm. The film creeps along at an unmercifully slow pace which only highlights the flaws (The Hollywood Reporter).

Lord passe de justesse la rampe: "The film [...] is terror-crammed and bloody enough to appeal to the raunchy circuit trade [...]", mais recueille plusieurs sarcasmes: "Jean-Claude Lord's direction seems obsessed with every synthetic cliché in the book, an impression reinforced by René Verzier's lensing " (Variety Film Reviews Index). The Film Journal souligne les qualités du film en regard du suspense et du sujet: "[...] how individuals living on the fringe of sanity may act on personal relations they only imagine between themselves and others made familiar to them through the media."

Les personnages représentés et les tentatives "surréalistes " de recréer leur univers intérieur sont perçus habituellement comme de terribles maladresses. Ces essais apparaissent comme des faiblesses sur le plan de la la direction cinématographique et des signes d'une "maladie» de l'imaginaire québécois demeuré provincial et sauvage: "Broodingly assured in its early scenes Night 
Zoo enters a lengthy period of dull delirium as Marcel attemps a rapprochement with his law-abiding dad" (The Village Voice).

De manière très claire, on privilégie les films dont les personnages sont très "terre à terre" et près du star system: "A film that's likely to become a talking point wherever it's shown, The Kid Brother is built entirely around it's 13-year-old-star" (Variety Films Reviews Index). Tous les réalisateurs québécois semblent incapables de bien camper leurs personnages, qui sont toutefois attachants. "However, what most impresses in Pouvoir intime is Simoneau's profiency in establishing sympathy for his characters, the script is skeletal, almost bare to the bone" (The Village Voice). Même Arcand dans Le Déclin de l'empire américain serait tombé amoureux de ses propres mots et semblerait incapable de distinguer ses personnages les uns des autres: "They all sound alike" (L. A. Life, Daily News).

\section{Moralité et traitement de la religion}

Deux tendances dans les films québécois sont décriées: l'obscurantisme de la religion et le caractère immoral. Le film de Jean-Claude Lord, Visiting Hours, est sévèrement critiqué:

About the only distinction this Canadian import has going for it is one of the most convoluted plots this side of General Hospital. Otherwise, it's your basic sicko-slasher movie, no more and no less offensive than the rest (Box Office).

But it's all just another reason to show women being abused. No matter how much they go on about supposed social issues, it's all canceled out by the apparent delight the camera takes in showing the killer kicking the wounded victim while he photographs her writhing in pain (Box Office).

Léolo abuse de références scatologiques, lorsque ce n'est pas tout simplement de références inutiles à la cruauté infantile: "But a miscalculated scene in which a gang of boys abuse a cat could easily be dropped to the film's overall benefit " (Variety). On n'a pas, non plus, relevé l'ironie de plusieurs séquences du film de Benoît, Comment faire l'amour avec un nègre sans se fatiguer, mais on a été plutôt sensible à son conformisme sexuel et à son 


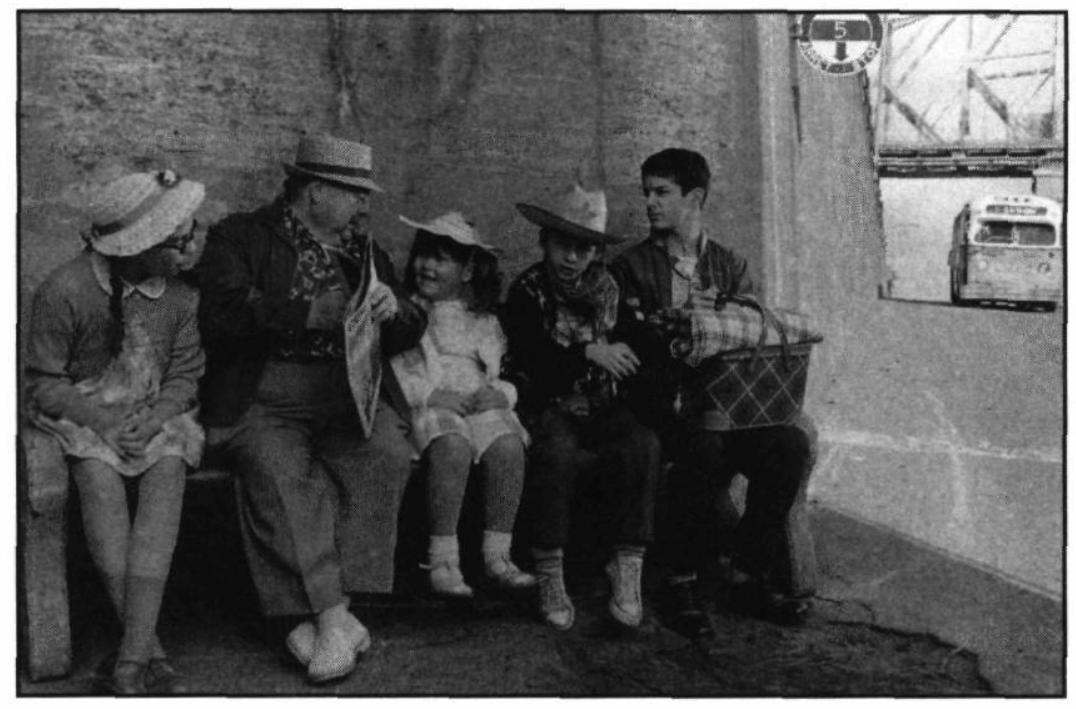

\section{Léolo de Jean-Claude Lauzon (1992)}

Collection Cinémathèque québécoise

caractère amoral. Finalement: "The film has more to do with offensive sexual stereotypes than with the racial ones suggested by its title" (The New York Times). Le Déclin de l'empire américain a aussi été perçu comme un film amoral:

[...] rated $\mathrm{R}$ for nudity and language (Herald Examiner).

The Decline's aural sex and unromantic view of human relationships is bound to offend some and bore others (The Film Journal).

At once moralistic and pandering the film is far more interested in flattering its audience than in confronting or moving them (The Village Voice).

Les cinéastes québécois seraient obsédés par le sexe, tout en étant profondément attirés par les référents religieux. En cela, les États-Uniens voient une référence au passé des Québécois, héritiers d'un puritanisme, mais voulant s'en distancier aujourd'hui par une pratique sexuelle débridée. Chose certaine, la critique a été très impressionnée par les rappels des rituels catholiques dans Maria Chapdelaine, Les Plouffe et Jésus de Montréal. De même 
pour Bay Boy, qui met en scène des éléments reliés au culte religieux et à la place sociale tenue par la religion. "The family travails, father's precarious fortunes, brother's debilitating disease, mother's profound religious guilt, [...] the murder of and old Jewish couple by a local policeman" (Variety Film Reviews Index). Bien que ces éléments, comme dans Maria Chapdelaine ou Les Plouffe, ne forment souvent qu'une toile de fond qui n'est jamais le centre véritable du film, la critique états-unienne y voit au contraire des références essentielles autour desquelles s'articulent ces films. A propos des Plouffe, on écrira: "Themes familiar to those who know the situation in Quebec, the heritage of strong Catholic influence, the cleric fight to maintain control over the family life [...]" (Variety Film Reviews Index). Et aussi : "The great parades and religious processions are captured in the first use of mass crowds in Quebecois cinema" (Variety Film Reviews Index).

Les critiques sont-ils d'autant plus friands de ces références que leurs films nationaux en sont expurgés? Cela les décontenance-t-il au point qu'ils en font souvent un élément important de leur critique ${ }^{4}$ ? Il faut rappeler la véhémence des polémiques auxquelles ont donné lieu, dans leur propre pays, un film comme The Last Temptation of Christ (Martin Scorsese, 1989). La critique du film de Denys Arcand, pour Jésus de Montréal, soulève toutefois moins de passion. Malgré le caractère provincial du film, il est moins provoquant que celui de Scorsese et fait moins référence aux aspects sexuels qui avaient tant choqué dans le film de l'Américano-Italien (Film Quarterly). De manière générale, les faiblesses qu'on reproche au film d'Arcand permettent aux critiques de le prendre moins au sérieux. Parfois, on lui reproche son manque de naturel et son type d'humour, parfois sa froideur. Pour plusieurs, Jésus demeure un film bien dirigé, mais néanmoins " $[\ldots]$ a very good film trying a little too hard to be a great one" (Newsweek).

Cette remarque résume le jugement de bon nombre de critiques sur l'ensemble des films québécois d'auteur, comme le rappelle l'un d'eux à propos du film de Francis Mankiewicz: "There are two kinds of Canadian films: tax-shelter productions in which too much is going on, and ethnographic exercises in which not enough is going on. Francis Mankiewicz's, Les Bons 
Débarras, fits more comfortably into the second category than into the first " (The Village Voice).

\section{Appréciation des acteurs, des procédés cinématographiques et de la narration}

La critique états-unienne demeure ambivalente dans son appréciation des talents cinématographiques québécois. D'une part les acteurs, d'autre part une bonne prise de vue et de son demeurent les points forts de la cinématographie québécoise:

Les Bons Débarras: The acting is good and it is a film with a realistic park and worth festival slotting. It just lacks a more filmic probing of these fairly barren lives (Variety Film Reviews Index).

Maria Chapdelaine: The performances are polished (Variety Film Reviews Index).

Visiting Hours: Performances in Visiting Hours are first rate (The Film Journal).

Le Déclin de l'empire américain: [...] is well-made, engrossing, very funny, with fine performances (New York Post). Arcand's film is an adroit mix of bitchery and deep feeling, impeccably performed by a fine cast (Film Comment).

Une prise de vue exceptionnelle semble la marque de commerce de bien des films, même si on n'en voit pas toujours la nécessité dramatique:

Maria Chapdelaine: The photography and art direction are flawless. The music composed by Lewis Furey, is somptuous and sometimes too loud and too present (Variety Film Reviews Index). Filming in the wilds of Northern Quebec, Mignot captures the terrible beauty of the rugged land (L. A. Life, Daily News). Michel Brault's photography contrasts the beauty of the mountains with the ugliness of rural poverty [...] André Corriveau's editing is crisp with hardly a superfluous frame (The Hollywood Reporter).

Pouvoir intime: Director Simoneau [...] knows how to suck you in: a sharklike steadicam cruises over a series of pool tables to introduce Theo's teenaged son [...] a 
tightrope walk across a girder by the androgynous female $[\ldots]$ and the gradual unhinging of Martial (The Village Voice). In addition to Guy Dufaux for precision and stylized camera work plaudits also go to art director Michel Proulx, editor André Corriveau and Richard Grégoire, for a pulsating score that perfectly ponctuates the proceedings (Variety Film Reviews Index). The film is undistractingly stylish, with hints of Welles in some spectacular longtake camera movements and an effectively nervous and stringy musical score by Richard Grégoire (The Village Voice).

Léolo: Technical credits are similarly superb, highlighted by Guy Dufaux's stunning cinematography and Richard Gregoire's ethereal score (The Hollywood Reporter).

Mais par ailleurs, de bons crédits techniques ne sont pas nécessairement l'équivalent d'un style cinématographique intéressant. Aussi note-t-on, chez Jean-Claude Lauzon, certains traits inhabituels :

Un zoo, la nuit: The soundtrack score has an eerie appeal. This is wasted here. If you can possibly hang on, don't walk out before the end, the film's final image, a variation on a Pietà, is a howler (The New York Times). In the madcap finale, however Lauzon goes the master one better with a spiritual safari to the outer limits of Hemingwayland (The Village Voice).

Pour qualifier des films où l'action demeure secondaire par rapport à l'univers intérieur, les critiques états-uniens parlent de «ton intellectuel» :

Les Bons Débarras: Above all, the tone of the film is intellectual rather than exploitational (The Village Voice).

Le Déclin: But this is a movie in which words, here cascades of French, speak louder than actions, and the question is whether this relentlessly articulate crowd of theorizers is worth listening. The answer alas, is both yes and no (Time).

Une caractéristique majeure est à souligner ici, qui fait l'unanimité des critiques: les productions québécoises sont handicapées par une narration boiteuse. 
Les Bons Débarras: The problem with the narrative is that it starts too late in the lives of the characters, and ends too soon, with none of the dangling conflicts resolved (Village Voice).

Visiting Hours:Typically for the genre, scripter Brian Taggert has furnished minimal plot and character and even less narrative logic (Variety Film Reviews Index).

The Bay Boy: Pic is handsomely mounted in all respects though music score tends to be intrusive at times. Story is much too busy and confusing to ultimately connect with mass audiences (Variety Film Reviews Index).

Pouvoir intime: French Canadian thriller that's more apt at visualizing the mechanics of the chase than making us give a damn about what happens to the players at the end of it (The Village Voice).

Les Plouffe: Watching this three-hour film is like sitting through a somewhat condensed but draggy television soap opera celebrating life, death, love, marriage, family ties [that do not bind] (The New York Times).

Comment faire l'amour avec un nègre sans se fatiguer: As adapted for the screen by co-screenwriter Richard Sadler, that format is kept intact, with desastrous results (The Hollywood Reporter).

Le Déclin de l'empire américain: While dramatically unremarkable, the happenings are largely static discussions, the production is nonetheless alive (The Hollywood Reporter).

De manière générale, les critiques sont sans merci pour les films québécois qui veulent imiter les genres états-uniens, que les films soient tournés en français ou directement en anglais.

\section{La réception critique états-unienne}

La critique connaît peu les auteurs québécois et donne peu d'informations sur leur carrière, à l'exception de quelques détails sur Gilles Carle, Denys Arcand et Jean-Claude Lauzon qui, au bout du compte, ne sont tout simplement que des données erronées: on soutient à tort que le premier film de Lauzon est $U_{n}$ zoo, la nuit et que Carle est un auteur très connu au Québec pour ses films sexy (La Tête de Normande St-Onge et Fantastica). 
La couleur locale intéresse particulièrement la critique étatsunienne, surtout lorsqu'il s'agit d'intrigues tournées loin des grandes cités. C'est particulièrement vrai pour Maria Chapdelaine (Lac St-Jean, Nord du Québec), Les Bons Débarras (Laurentides) et Bay Boy (Glace Bay, Ile-du-Cap-Breton, NouvelleÉcosse). Elle y trouve des correspondances entre les paysages arides, découpés, isolés et les sentiments bruts de plusieurs personnages principaux.

Par contre, le choix de lieux citadins liés aux films de genres, dans lesquels excellent les États-Uniens, rend la critique beaucoup plus sévère. Visiting Hours, Pouvoir intime et Un zoo, la nuit sont soumis à un feu croisé particulièrement virulent. On leur reproche leur vision étriquée, en plans serrés, d'univers complexes; on condamne les caractères stéréotypés et la narration schématique.

Seul échappe à la règle Léolo, pourtant tourné dans un petit nombre de lieux grâce (disent les États-Uniens) à son sens de la poésie, du grotesque et de la fantaisie. Maria Chapdelaine, $U n$ zoo, la nuit, Les Bons Débarras, Pouvoir intime en impressionnent aussi plus d'un par les qualités cinématographiques de la photographie, de la musique et du montage.

Pourtant, les critiques insistent à plusieurs reprises sur la dramatique générale des films québécois, qui serait toujours responsable du manque d'intérêt prévisible du futur spectateur. L'évolution de l'histoire et les rapports entre les personnages poseraient problème. Bref, disent-ils, une intrigue peu soutenue et une finale déroutante rebutent le spectateur. Il faut d'ailleurs mettre ces jugements en relation avec les comparaisons faites entre le cinéma québécois et les auteurs étrangers. La critique états-unienne éprouve de sérieuses difficultés à raccrocher le cinéma québécois à d'autres courants cinématographiques nationaux, à faire des rapprochements avec des auteurs étrangers. $U n$ zoo, la nuit ressemblerait un peu à Diva, Pouvoir intime serait influencé par Melville, Le Déclin par des films états-uniens et anglais sur le couple. Implicitement, les films québécois sont constamment dévalorisés en fonction des critères esthétiques hollywoodiens en ce qui a trait au fonctionnement du récit, à l'organisation de l'intrigue et au non-respect des lois qui 
régiraient la finale d'un film. Les finales ambivalentes, ou en queue de poisson, les héros qui démissionnent sans fracas, tout cela choque et déçoit. La réception éventuelle du public sert alors d'excuse, de panacée pour classer le film dans la catégorie limitative "pour public averti ". Comme le rappelle Robert Dôle:

\begin{abstract}
[...] à l'insu des Américains, il existe un caractère américain, une mentalité américaine, un comportement américain qui sont propres au peuple américain et qui le distinguent d'autres nationalités. Les Américains, par contre, tendent à croire que leur mentalité est universelle. La manière de penser et d'agir des Américains remonte au XVII siècle. Ces derniers pensent généralement que leurs politiques gouvernementales et leurs relations interpersonnelles dérivent de la nature universelle de l'homme et des lois de la logique (p. 12).
\end{abstract}

Cette attitude s'appuie à la fois sur des jugements moraux et esthétiques. Les films québécois déroutent en partie, et il ne s'agit pas, selon la critique, de faiblesses reliées à la prise de vue, de son ou à l'enregistrement musical. Au contraire, ce sont des talents périodiquement soulignés comme points forts de la cinématographie des auteurs québécois. Bref, il y aurait d'un côté le savoir-faire notable des techniciens et de l'autre celui de réalisateurs à la morale douteuse, habiles à camper paysages et personnages typiques, mais incapables de soutenir une intrigue de manière classique (actions, rebondissements, finale précise).

Lorsque nous avons abordé la réception des films québécois en France, nous avons montré comment la critique française était stimulée par le pittoresque québécois, les différentes pratiques des auteurs et par la question de l'accent ${ }^{5}$. Les ÉtatsUniens semblent aussi fascinés par la rudesse du pays et les grands espaces, mais le pittoresque des caractères ne les intéresse pas autant. Ils sont beaucoup plus sensibles à la manière de faire et aux questions relatives à la morale, à la religion. Les Français n'ont jamais soulevé beaucoup de questions esthétiques reliées à la fiction québécoise, ils ont plutôt concentré leurs remarques sur la propension au direct du cinéma de fiction. La critique française éprouve aussi une nostalgie certaine pour tout le 
cinéma québécois "nouvelle vague», documentaire et d'auteur des années soixante. Ils y découvraient des cousins. À l'opposé, nos voisins états-uniens montrent peu d'intérêt pour le développement de notre cinéma. Ils abordent chaque film indépendamment de la cinématographie d'un auteur et de la cinématographie québécoise dans son ensemble. En conséquence, ils s'étendent rarement sur la place particulière d'un film, son originalité. Ils préferent se positionner du point de vue des consommateurs pour recommander ou non un film. Leur référence demeure le cinéma hollywoodien et son esthétique. Pour de nombreux critiques, comme pour les magnats états-uniens du cinéma, le cinéma québécois, pour être apprécié, "must still be part of the domestic market ".

Pourtant, les commentaires critiques laissent entendre que le Québec est différent, mais cette différence n'est pas perçue comme une autre américanité venant d'une histoire différente:

This is Quebec after the fall into modernity forecast by Plouffe père in his most pessimistic moments. And if the characters still speak french, their lifestyle is something like third world modern; the worst aspects of underdevelopment and overdevelopment bound together by the cult of the fast buck (The Village Voice).

Cette altérité s'impose dans les textes comme un manque, une sorte de tiers monde à leur porte. L'attitude de leurs auteurs suggère qu'ils sont à la fois parfaitement conscients des différences, mais mal à l'aise, sans véritable intérêt intellectuel pour ce qui est inconnu. Certains vont jusqu'à tirer les conclusions suivantes:

On ne peut s'empêcher de penser que la volonté d'ignorer ce qui se passe en dehors des frontières américaines, alliée à un style de vie d'une extrême facilité qui demeure celui de l'ensemble de la bourgeoisie américaine, - fait d'une absence totale de problèmes quotidiens, de ce profond sentiment de sécurité qui découle de la position géographique même de l'Amérique, jamais envahie, jamais préoccupée, jamais sujette aux soubresauts qui font partie de l'héritage culturel du monde, - cette ignorance volontaire explique le côté 
obsessionnel, à la limite absurde, de ces colères tous azimuts, de cette acceptation totale d'un conformisme aussi simpliste que revendicatif en ce qui concerne les nouveaux droits des anciens opprimés [...] (Behr, p. 317).

Chose certaine, il suffit de comparer comment des critiques européens ont minutieusement étudié, analysé et perçu le cinéma québécois ${ }^{6}$ pour ressentir cet ethnocentrisme condescendant d'une critique états-unienne et mesurer le peu d'empathie qu'elle éprouve à l'égard de la culture de ses "petits voisins ${ }^{7}$ ".

\section{Cégep du Vieux-Montréal}

\section{NOTES}

1 Voir Bernard Bérubé et Richard Magnan, Les Films québécois dans la critique américaine. Répertoire analytique 1960-1979 (Montréal : Centre de recherche cinéma/réception et Cinémathèque québécoise, 1994).

2 Ces textes sont répertoriés dans les deux répretoires dirigés par Bernard Bérubé et Richard Magnan, Les Films québécois dans la critique américaine. Répertoire analytique 1960-1979 (Montréal: Centre de recherche cinéma / réception / Cinémathèque québécoise, 1994) et Les Films québécois dans la critique américaine. Répertoire analytique 1980-1992 (Montréal: Centre de recherche cinéma / réception et Cinémathèque québécoise, 1994).

3 Cette citation est tirée d'une communication donnée par Michel Larouche intitulée Imaginaire américain et cinéma québécois (texte non publié), au sein de la session "Québec-USA: l'influence de la culture américaine" dans le cadre du colloque de l'American Council for Quebec Studies, Washington, 17-20 novembre 1994 (titre du colloque: "Tradition and Change: Quebec Approaching the 21st Century "\}.

4 Voir Robert Dôle, Le Cauchemar américain. Essai sur les vestiges du puritanisme dans la mentalité américaine actuelle (Montréal : VLB éditeur, 1996).

5 Voir l'ouvrage sous la direction de Michel Larouche, L'Aventure du cinéma québécois en France (Montréal: XYZ éditeur, 1996).

6 Voir Ian Lockerbie: "Quebec Cinema as a Mirror of Identity ", dans C.H.W. Remie et J.- M. Lacroix (ed.), Canada on the Threshold of the 21st Century, European Reflections upon the Future of Canada (Amsterdam / Philadelphia: John Benjamins Publishing Co., 1991), p. 301-307. Et pour un point de vue très différent des textes des journaux états-uniens répertoriés dans cet article, voir la critique universitaire états-unienne, Doris Pyee-Cohen, "Histoire, culture et civilisation du Québec par son cinéma ", Cinébulles, vol. 12, n 4 (1993), p. 24-26.

7 Sur les relations entre petits et grands voisins, voir Les Grands Voisins (Bruxelles: Éditions de l'Université de Bruxelles, 1984), et sous la direction de Claude Savary, Les Rapports culturels entre le Québec et les États-Unis (Québec: Institut de recherche sur la culture, 1984). 


\section{OUVRAGES CITÉS}

Behr, Edward. Une Amérique qui fait peur. Paris: Plon, 1995.

Dôle, Robert. Le Cauchemar américain. Essai sur les vestiges du puritanisme dans la mentalité américaine actuelle. Montréal: VLB éditeur, 1996.

Knight, Arthur, "Canadian Films at the Crossroads". The Hollywood Reporter, 19 septembre 1980.

\section{CORPUS CRITIQUE CITÉ}

The Bay Boy:

Variety Film Reviews Index, Leonard Klady, vol. 18, 23 mai 1984.

Box Office, Alan Karp, vol. 121, n 8, août 1985.

The Hollywood Reporter, Bill Desowitz, 30 mai 1985.

The New York Times, Herbert Mitgang, 15 février 1985.

Les Bons Débarras:

Variety Film Reviews Index, Mosk, vol. 15, 5 mars 1980.

The New York Times, Janet Meslin, 15 janvier 1981.

The Village Voice, Andrew Sarris, 28 janvier 1981.

The Hollywood Reporter, Charles Ryweck, 31 décembre 1980.

The Hollywood Reporter, Arthur Knight, 19 septembre 1980.

Comment faire l'amour avec un nègre sans se fatiguer:

Variety Film Reviews Index, Suzan Ayscough, vol. 21, 15 mars 1989.

The Village Voice, Julie Phillips, 12 juin 1990.

The Hollywood Reporter, Dwight Brown, 6 juin 1990.

The New York Times, Janet Maslin, 8 juin 1990.

Le Déclin de l'empire américain:

Time, Richard Schickel, vol. 129, n” 3, 19 janvier 1987.

Film Comment, Elliott Stein, vol. 22, n 6, novembre-décembre 1986.

New York Post, Jami Bernard, 29 septembre 1986.

L. A. Life, Daily News, Kirk Honeycutt, 21 novembre 1986.

The Hollywood Reporter, Duane Byrge, 13 novembre 1986.

Los Angeles Weekly, John Powers, 21-27 novembre 1986.

The Film Journal, Wendy Weinstein, vol. 89, n 11, décembre 1986.

Herald Examiner, Deborah J. Kunk, 21 novembre 1986.

The Village Voice, Andrew Sarris, 2 décembre 1986.

Jésus de Montréal:

The Village Voice, Georgia Brown, 29 mai 1990.

Newsweek, David Ansen, 12 mars 1990.

Films in Review, Maria Garcia, vol. XLI, n' 10, octobre 1990.

The Film Journal, Doris Toumarkine, vol. 93, n“ 5, juin 1990.

Film Quarterly, Tom O’Brien, vol. 44, n 1, automne 1990.

The Kid Brother:

Variety Film Reviews Index, vol. 20, 2 septembre 1987. 
Léolo:

Variety, David Stratton, 1" juin 1992.

The Hollywood Reporter, Michael Rechtshaffen, 11 septembre 1992.

The New York Times, Peter Brunette, 28 mars 1992.

Maria Chapdelaine:

L.A. Weekly, Helen Knode, 25 avril. 1986.

Variety Film Reviews Index, Zerb, vol. 18, 4 mai 1983.

Box Office, Tom Matthiews, vol. 122, n 7, juillet 1986.

L. A. Life, Daily News, Kirk Honeycutt, 3 mai 1986.

The West Hollywood Paper, Clair Peterson, 24 avril 1986.

Daily Breeze, Jerry Roberts, 30 avril 1986.

The Hollywood Reporter, Ed. Kaufman, 8 mai 1986.

Les Plouffe:

The Village Voice, Enrique Fernandez, 26 novembre 1985.

Variety Film Reviews Index, vol. 17, 29 avril 1981.

The Hollywood Reporter, Tina Daniell, 19 mars 1982.

The New York Times, Vincent Canby, 15 novembre 1985.

Pouvoir intime:

The Village Voice, Katherine Diekmann, 17 nov. 1987.

Variety Film Reviews Index, Bro (coll.), vol. 19, 19 mars 1986.

The Village Voice, Elliott Stein, 27 janvier 1987.

Un zoo, la nuit:

The Village Voice, Jim Hoberman, 5 avril 1988.

Variety Film Reviews Index, Sid Adilman, vol. 20, 13 mai 1987.

The Film Journal, D.,N., vol. 91, n 4, mai 1988.

Films In Reviews, Robert Pardi, vol. 39, n 5, mai 1988.

The New York Times, Vincent Canby, 30 mars 1988.

Visiting Hours:

Box Office, Jimmy Summers, vol. 118, nº 7, 15 juillet 1982.

Variety Film Reviews Index, Pit, vol. 17, 5 mai 1982.

The Hollywood Reporter, Robert Osborne, $1^{\text {er juin } 1982 .}$

The Film Journal, David Shifren, vol. 85, n 15, juin 1982.

CineFantastique, Jordan R. Fox, vol. 12, n 4, mai 1982.

Cinémas, vol. $7, \mathrm{n}^{\circ} 3$ 